\title{
Data-driven gameplay experience balancing
}

\author{
Pejman Mirza-Babaei \\ Faculty of Business and Information Technology \\ University of Ontario Institute of Technology (UOIT) \\ pm75@sussex.ac.uk
}

\begin{abstract}
The overall aim of developing a game that is fun to play is often hard to achieve due to the complexities of the game development process. An accurate understanding of player behavior and their gameplay experiences can help identify and resolve any potential problem areas before release. In this keynote, I will use commercial case studies and academic research projects to provide a summary of my work in developing new evaluation methodologies, tools and data visualizations for games UX evaluation. I will discuss approaches and provide guidelines on how game developers and researchers can benefit from gameplay data to optimize player experience.

\section{SHORT-BIO}

Dr. Pejman Mirza-Babaei é professor de User Experience (UX) Research e Diretor Adjunto de Relação com a Indústria na Faculty of Business and Information Technology da Ontario Tech University. Sua pesquisa e ensino foca no design e avaliação da experiência do usuário em sistemas de entretenimento interativo. Ele publicou mais de 50 artigos e frequentemente fala em conferências acadêmicas e eventos da indústria. Ele também é coeditor do livro "Games User Research". Pejman trabalhou na avaliação pré e pós-lançamento de mais de 25 jogos comerciais, incluindo títulos premiados como Crysis 2, PewDiePie: Legend of the Brofist e Weirdwood Manor. Ele também atuou como diretor de pesquisa de UX no Execution Labs (Montreal, Canadá) de 2015 a 2017 e foi pesquisador de UX na Vertical Slice / Player Research (Reino Unido) de 2009 a 2013.
\end{abstract}

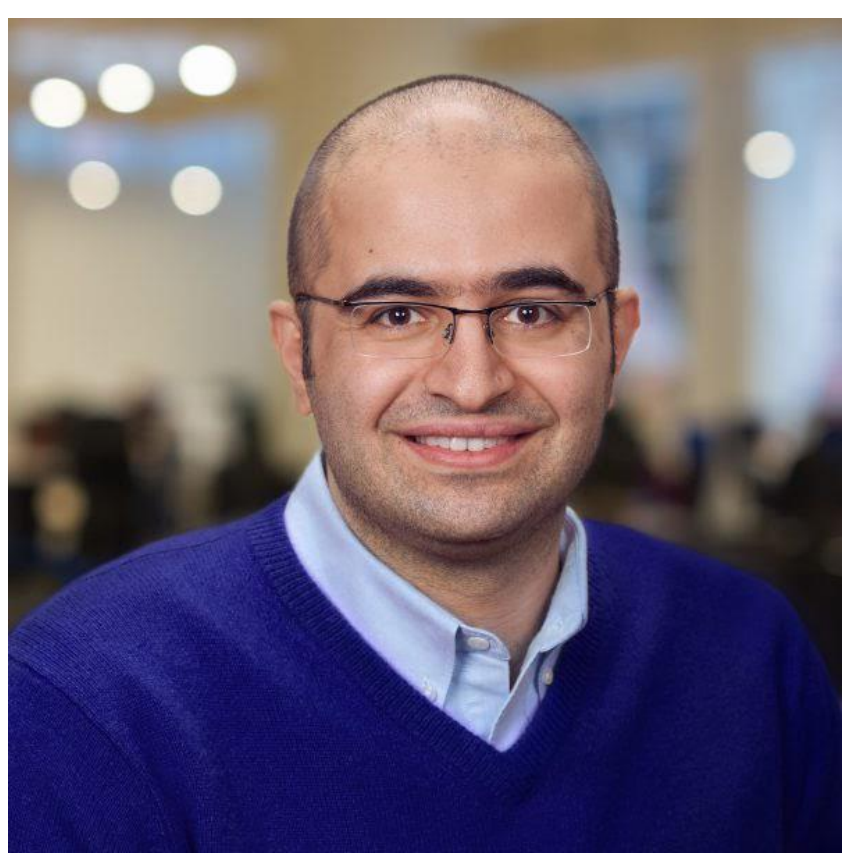

Figure 1. Pejman Mirza-Babaei

Permission to reproduce or distribute, in whole or in part, material extracted from this work, verbatim, adapted or remixed, as well as the creation or production from the content of such work, is granted without fee for non-commercial use, provided that the original work is properly credited.

IHC 2020 - Plenárias, Outubro 26-30, 2020, Ciberespaço, Brasil. In Anais Estendidos do XIX Simpósio Brasileiro sobre Fatores Humanos em Sistemas Computacionais. Porto Alegre: SBC.

C2020 by the author(s), in accordance with the terms of the Creative Commons Attribution-NonCommercial 4.0 International Public License (CC BY-NC 4.0) 